\title{
Notes on the Plankton observed at Plymouth during June, July, August and September, 1892.
}

\author{
By
}

\section{Edward J. Bles, B.Sc.,}

Hon. Research Fellow in the Owens College.

THE absence of systematic records showing the variations of the floating fauna and flora, or plankton, of the Plymouth waters is much to be regretted. My observations on the amount of animal and plant life suspended in the sea from the surface to the bottom would show that in comparison with similar observations made elsewhere, the quantity of plankton in this locality was during the past summer surprisingly small. The absence of data upon which comparisons could be based between the state of the water in this season and that obtaining in former years is all the more to be deplored because the present season has in many respects been a remarkable one. In the first place, the Plymouth mackerel fishery has so far been a complete failure; it has further been found that dog-fishes (both Scyllium and Acanthias) were not obtainable during June and July ; and lastly, Aurelia aurita, which in summer is usually common, was extremely scarce in the Sound and tidal waters of Plymouth. If my surmise that the amount of plankton was for the locality exceptionally small proves correct, then these three salient instances of scarcity of animals which are directly or indirectly dependent on the plankton for their food will suffice to show the importance of a series of more or less continuous observations on the physical and biological condition of the inshore and Channel waters. Were accurate information on these points available, it would in all probability enable us to explain, and we might even in time be able to foresee, the occurrence of so important an event as the exceptionally sporadic appearance of the mackerel in 1892 .

The quantitative and faunistic observations I have made with the aid of a Royal Society grant are made with this object in view, but it will be some time before the results are ready for publication, and it may now be of interest to record some extracts from my diary.

June 17th.-Hormiphora plumosa, the Ctenophore common at 
Plymouth, was not seen in the adult condition after this date, but at the middle of September minute young Hormiphora made their appearance and ova were found, but the adult was absent from hauls which otherwise were in excellent condition.

The Hydroid medusa, Obelia lucifera, was very plentiful throughout June. It was interesting to note the effect of killing the medusæ in the dark. On adding a saturated solution of corrosive sublimate to the sea water the stimulus caused the animals to become phosphorescent, and the position of each medusa was indicated by a small clear ring of blue light round the margin of the umbrella. The light did not fade until after about a minute.

June 21st.-From this day onwards Porcellana zoœa have occurred almost constantly. On June 28th Appendicularia were first observed, and on July 4th they became very common, chiefly belonging to the species Oikopleura cophocerca. Of this form young specimens abounded.

Rhizoselenia obtusa and R. setigera, two diatoms with immensely elongated frustules, began to occur in large numbers on July 4th. On this day, moreover, Evadne appeared, together with the other marine Cladoceran Podon which hitherto had been the only representative of the group. Evadne gradually increased in numbers, while Podon gradually became scarcer, disappearing near the middle of September. Evadne constantly produced swarms of ephippial young, and is still bearing ova and larvæ (1st October), but about the middle of September they commenced to produce their large winter eggs, one egg in each individual. Another feature of the haul on July 4th was the great increase in the quantity of Dinoflagellates, Ceratium tripos, C. fusus, and Peridinium sp. Both the Dinoflagellates and Rhizoselenia are known to be more abundant towards the south-west and near the ocean, and on June 25th I found Evadne in large numbers off the French coast, sixty to seventy miles south of Plymouth.

The sudden appearance on July 4 th of these various forms from the south and south-west may perhaps be explained. On June 28 th the wind in the western part of the channel was light and variable, but from then until July 3rd-4th it blew from a westerly quarter (S.W. and W.S.W.), freshening on July 3rd. These facts seem to indicate that the wind has a very marked influence on the distribution of plankton. This conclusion is strongly supported by the fact that oceanic Radiolaria belonging to Haeckel's Acantharia also occur in the same haul of July 4th. Mr. Bourne, in his Report of a Cruise in H.M.S. "Research" off the Southwest Coast of Ireland, remarks, "The absence of pelagic Radiolaria at Plymouth has often engaged my attention,"* and records the

* This Jourual, vol, i, p. 321. 
occurrence of several species in "tolerable abundance" amongst them an Acanthometron, which may be identical with mine. On no other occasion have I seen Radiolaria at Plymouth, and this sudden appearance, together with that of the other organisms mentioned, very probably indicates that the surface-layers of the sea with their plankton are displaced through considerable distances by the prolonged or powerful action of the wind in one direction.* It is desirable that this observation should be extended and confirmed, as it has obviously an important bearing on the distribution of the food of migratory fishes like the herring and mackerel.

July 23rd.-Saphenia mirabilis, Haeckel, was taken at the bottom in 9 fathoms off Penlee Point. The specimens were of the same size as those recorded by Mr. J. T. Cunningham in this Journal, vol. ii, page 194. The haul also contained a number of frene-viriduta, Esehsefor, a medusa which was almost invariably present in the bottom tow-nettings from June to August. Once only did they appear in a surface netting, and that was one taken soon after midnight on July 21st in Start Bay.

August 26th.-The Siphonophore Muggiæa atlantica, Cunningham, made its appearance. The eudoxomes were at this time immature, and were not observed to be detached until September 2nd, when they bore ripe sexual products in the manubrium of the genital nectocalyx. Later on (23rd September) I found the young Calyconula larva corresponding to a figure by Chun in the Ann. and Mag. Nat. Hist., ser. 5, vol. xi, pl. v, fig. 6 . This was at a time when the adult oecurred in very large numbers, and just before it began to become scarce.

September 5th.-The pelagic larva of the interesting Polychæte, Magelona papillicornis, Fr. Müll., was plentiful for a fortnight after this date, and then began to diminish in numbers; at the end of the month only stray specimens were found.

September 10th.-Young Amphioxus larvæ were taken just outside the Breakwater. A few more at a slightly later stage were taken on 13th and 17th September, with sixteen to seventeen primary gill-slits.

September 23rd.-Müller's larva (Polyclad) was first noticed and was frequently found during the ensuing week. In August and September the surface tow-nettings often contained a young Polyclad, probably Leptoplana, from $1 \frac{1}{2}$ to $2 \mathrm{~mm}$. in length.

September 24th.-The absence of Noctiluca is a very extraordinary feature of the year, for 1891 was remarkable for the immense pro-

* Dr. John Murray informed me that Radiolarians had not been taken in the Clyde area until I found them, after the prolonged south-westerly gales of 24th to 26th August, in a tow-netting taken from the yacht "Medusa," off Rothesay, Bute, 
fusion of this infusorian, which in the months of June and July was present in such numbers that it discoloured large stretches of sea. This year it has been almost entirely absent, and a few individuals which I found at the end of September were the only signs of its existence. There were no great displays of phosphorescence this summer, either in the Sound or in the Channel, on the occasion of my nocturnal excursions.

September 30th.-Two species of Copepods which, according to Bourne (this Journal, vol. i, pp. 150 and 151) have only been taken here from February to May, I found outside the Breakwater in September. They are Euterpe gracilis and Corycæus anglicus, the former being fairly plentiful. During the whole summer Cetochilus septentrionalis has been present, but never in large numbers, each tow-netting generally containing a few.

In the last days of September a marked increase in the number of Dinoflagellates took place, and among them a form appeared which seems to be intermediate between Dinophysis and Ornithocercus, but which I have not yet identified.

I have collected a number of interesting Annelid and Mollusc larvæ, which I have not mentioned above, as I hope to report on them in detail elsewhere.

I have found that it is easy to rear Annelid and other larvæ by the following method :-The whole of a tow-netting in a large confectionery jar full of pure sea-water may be placed up to its neck in a tank through which water circulates. If the tow-netting is rich in species but poor in individuals, a large number of larvæ will live and continue to develope. Such a tow-netting I obtained on September 5th, and in seven to ten days later, after keeping the bottle at a constant low temperature in the way described above, I found on the sides of the bottle young Serpulids in tubes, a few two- three- aud four-celled colonies of Membranipora and young bivalve molluses in the prodissoconch stage. I also found four specimens of Protodrilus leuckartii, Hatschek, a most interesting Archiannelid which has until now, I believe, not been recorded from any other locality but the Mediterranean and Black Sea. 